\title{
Rевевсн Автіск: Participation of rural women in agricultural and allied activities
}

\section{UMESH R. CHINCHMALATPURE, R.T. KATOLE AND G.B. MORE}

Article Chronicle: Received :

11.04.2015;

Revised :

02.07.2015;

Accepted :

03.08.2015

KeY WoRds:

Participation, Rural women, Agricultural, dairy and household activities
SUMMARY : The study was carried out in Akola district of Maharashtra state. An exploratory design of social research was used. A sample of 100 rural women as respondents were drawn and information was obtained from them which was considered for tabulation and analysis of data. Findings revealed that the majority of the rural women were middle age, illiterate, married, landless, medium family size and joint family. The higher percentage of rural women were with annual income upto Rs. 25000/-. Majority of the respondents always participated in cleaning of the field, sowing, weeding, thinning, harvesting/ cutting/picking, winnowing, drying of grains and cleaning of grains as related to agricultural activities. In case of dairy activities only 45 respondents were found. Out of them majority were participated in dairy activities like cleaning of cattle and cattle shed, collection of cow dung. Regarding household activities all the selected activities like washing clothes, rearing of children, cooking related activities, cleaning and decoration of home, fetching of water and buying of cooking ingredients, fruits, vegetables etc. were performed by the majority of rural women. Majority of the rural women expressed their problems in participation of agricultural and allied activities like less wage rates received, health problems and poor economic condition.

How to cite this article : Chinchmalatpure, Umesh R., Katole, R.T. and More, G.B. (2015). Participation of rural women in agricultural and allied activities. Agric. Update, 10(3): 187-193.
Author for correspondence :

\section{UMESH R.}

\section{CHINCHMALATPURE}

Department of

Extension, College of

Agriculture, Dr.

Panjabrao Deshmukh

Krishi Vidhyapeeth,

AKOLA (M.S.) INDIA

Email: rcumesh@

rediffamil.com

See end of the article for

authors' affiliations 